\title{
„Peir leika saman og eru glaðir, pað er bara svo gott“: Félagsleg tengsl og vinátta leikskólabarna af erlendum uppruna
}

\author{
Eyrún María Rúnarsdóttir og Svava Rán Valgeirsdóttir
}

Abstract Um höfundana

About the authors

Heimildir

\begin{abstract}
Niðurstöður rannsókna benda til pess að vina- og félagatengsl grunnskólabarna og unglinga af erlendum uppruna séu brothættari en tengsl sem íslenskir félagar peirra njóta. Á leikskólastiginu skortir sambærilegar rannsóknir en par er viðurkennt að samskipti barna og frjáls leikur sé einn pýðingarmesti páttur námsins. Markmið eigindlegrar rannsóknar sem hér er kynnt er að skyggnast í samskipti, leik og vinatengsl leikskólabarna af erlendum uppruna. Rannsóknin var gerð í leikskóla í sjávarbyggð. Alls tóku 21 barn af einni leikskóladeild pátt í rannsókninni en lykilpátttakendur voru fjögur 5-6 ára gömul börn, tvær stúlkur og tveir drengir. Tvö peirra áttu tælenska foreldra og tvö áttu pólska foreldra. Gögnum var safnað með hópviðtölum, paraviðtölum og einstaklingsviðtölum, myndbandsupptökum og vettvangsathugunum. Að auki teiknuðu börnin myndir af vinum sínum og tóku ljósmyndir í leikskólastarfinu. Félagsleg staða barnanna fjögurra reyndist viðkvæm en pó nutu pau flest gagnkvæmrar vináttu. Takmörkuð færni í íslensku og fá tækifæri til samskipta utan leikskóla höfðu hamlandi áhrif á félagsleg tengsl peirra innan barnahópsins og fram komu dæmi um höfnun og útilokun. Niðurstöður benda til að stuðningur leikskólakennara í samskiptum peirra við önnur börn hefði getað tryggt betur virka pátttöku peirra í skólastarfinu. Í pessu skyni er mikilvægt að pekkja aðferðir barnanna til að komast inn í leik og stofna til kynna. Skerpa mætti jafnframt hlutverk skólans og kennara við að styðja og leiðbeina foreldrum barna af erlendum uppruna og hvetja pannig til aukinna tengsla við önnur börn í leikskólanum. Markmiðum skóla án aðgreiningar verður aðeins náð ef öll börn hafa jafnan aðgang að lærdómsferli leikskólans.
\end{abstract}

Efnisorð: Börn af erlendum uppruna, skóli án aðgreiningar, vinátta, leikskóli, félagsleg tengsl, skóli án aðgreiningar

\section{Inngangur}

Samskipti og frjáls leikur gegnir lykilhlutverki í námi leikskólabarna enda er í Ađalnámskrá leikskóla (Mennta- og menningarmálaráðuneytið, 2011) lögð áhersla á að í leikskóla skuli efla færni barna í samskiptum, stuðla að félagslegum tengslum og próun samkenndar, tillitssemi og vináttu. Pá er lögð áhersla á virðingu fyrir margbreytileika mannlífs og að pörfum allra barna sé mætt án tillits til bakgrunns, getu eða aðstæðna. Unnið skal í anda hugmyndafræði um skóla án aðgreiningar. 
Samkvæmt Hagstofu Íslands (2018) eru um 12\% leikskólabarna með erlent móðurmál og er pólska móðurmál 41\% peirra. Áherslur námskrár um skóla án aðgreiningar, virðingu fyrir margbreytileika og að stuðlað sé að félagslegum tengslum barna eru afar pýðingarmiklar í pessu ljósi.

Íslenskar rannsóknir hafa leitt í ljós að börn og unglingar af erlendum uppruna á grunnskólaaldri standa höllum fæeti félagslega. Pau upplifa síður stuðning frá bekkjarfélögum en íslenskir félagar peirra (Eyrún María Rúnarsdóttir og Rúnar Vilhjálmsson, 2015), eiga færri vini, er strítt, pau skilin út undan (Hrefna Guðmundsdóttir og Hanna Ragnarsdóttir, 2013) og meiri líkur eru á að pau verði fyrir einelti (Póroddur Bjarnason, 2006). Sambærilegar rannsóknir hafa ekki verið gerðar á leikskólastigi en vísbendingar eru um að lakari staða í tungumáli og árekstrar 1 heimamenningu og skólamenningu torveldi leikskólabörnum af erlendum uppruna aðgang að námsferli sem á sér stað í leikskóla í gegnum frjálsan leik, félagsleg samskipti og vináttu (Brooker, 2002; Hanna Ragnarsdóttir, 2002). Brýnt er að skoða betur hvernig leikskólabörnum af erlendum uppruna gengur að fóta sig í samskiptum í hópi jafnaldra en aukinn skilningur er forsenda pess að hægt sé að grípa betur inn í og styðja börnin par sem stuðningur kemur sér best.

Í greininni er fjallað um eigindlega rannsókn á félagslegum tengslum og vináttu leikskólabarna af erlendum uppruna á aldrinum 5-6 ára. Sjónum er beint að samskiptum peirra við öll önnur börn á leikskólanum óhád uppruna. Byggt er á meistaraverkefni annars höfundar, Svövu Ránar Valgeirsdóttur. Rætt var við börnin og fylgst með leik peirra. Með pví fengu börnin tækifæri til að koma sjónarmiðum sínum á framfæri.

Niðurstöður fyrri rannsókna sem benda til brothættrar stöðu barna og unglinga af erlendum uppruna pegar kemur að félagslegum tengslum, gefa tilefni til að spyrja nánar hver staðan sé í leikskólanum. Markmið rannsóknarinnar sem hér er kynnt var að skoða félagsleg tengsl, vináttu, samskipti og leik 5-6 ára leikskólabarna af erlendum uppruna í peim tilgangi að benda á hvernig styðja megi pau betur og bæta stöðu peirra í jafningjahópnum.

\section{Fræðilegur bakgrunnur}

\section{Vinátta, leikur og félagsleg tengsl leikskólabarna}

Á aldrinum 4-6 ára eru vinasambönd orðin mikilvægur og stöðugur páttur í lífi margra barna. Börn hafa pá væntingar um gagnkvæma vináttu sem eykst samhliða hækkandi aldri (Bagwell og Schmidt, 2011). Um fjögurra ára aldur geta börn sagt til um hverjir eru vinir peirra og hverjir ekki (Boivin, 2005). Í rannsókn í sænskum leikskólum kom í ljós að um 75\% bjuggu við gagnkvæm vinatengsl, $11 \%$ völdu sjálf vin en voru ekki valin til baka og 5\% barna töldu sig ekki eiga vin í leikskólanum. Var petta nokkuð jafnt á milli drengja og stúlkna (Fanny Jónsdóttir, 2007).

Vinátta barna á leikskólaaldri skiptir máli enda tengist vinátta og samskipti við önnur börn proska og námi. Sebanc (2003) bendir á að barn öðlist betri pekkingu um sig og aðra og um heiminn í heild sinni í gegnum samskipti við önnur börn. Barnið styrkir sig tilfinningalega og vitsmunalega í gegnum samvinnu og samvirkni. Að eiga vin við upphaf grunnskólagöngu tengist jákvæðari aðlögun að skólastarfinu (Ladd, Birch og Buhs, 1999) og vinatengslin fyrirbyggja einmanaleika (Dunn, 2004).

Í gagnvirkum samskiptum jafningja próast vináttumenning sem einnig er nefnd jafningjamenning. Hún próast í samskiptum og felst í stöðugum venjum, gildum og áliti sem mótast meðal jafningja. Pættir eins og kyn, kynpáttur og félagsleg staða geta haft áhrif á jafningjamenningu í gegnum pað hvernig börn túlka og tjá pekkingu sína og skilning á siðum og venjum í umhverfinu (Corsaro, 2011). Í samskiptum barna fer fram tiltekin félagsmótun en par gegnir pykjustu- og hlutverkaleikur mikilvægu hlutverki. Barnið æfir og mátar sig við hlutverk sem hafa tilfinningalegt gildi og merkingu í samskiptum við önnur börn (Manning-Morten og Thorp, 2003). Kennarar purfa pví að gera sér grein fyrir mikilvægi leiks í félagsmótun barna og pví að leikurinn er jafnframt 
undirstaða vinatengsla peirra.

Um leið og börn ákveða að leika saman pýðir pað að pau eru vinir á meðan leikurinn er í gangi (Corsaro, 2003). Rannsóknir Corsaro hafa sýnt að börn veigra sér við að spyrja beint hvort pau megi vera með í leik pví að pá er möguleiki að fá höfnun. Börn nota frekar leiðir til að komast inn í leik, svo sem óyrta inngöngu (e. nonverbal entry) en pá fylgist barn með leik annarra barna og gefur í skyn að pað vilji vera með í von um að vera boðið í leikinn. Önnur leið barns er að hringsóla (e. encirclement) í kringum leikinn eða að byrja hljóðlega að leika í svipuðum leik samhliða. Driðja leiðin er að barnið velur félaga, býður fram hluti eða vísar í tengsl sín á milli (e. verbal reference) og staðfestir pátttöku með fullyrðingum líkt og „við erum vinir, er pað ekki?““ Með pessu móti er líklegt að hinum börnunum finnist sér ekki vera ógnað enda fer nýja barnið inn í pær leikreglur sem eru fyrir hendi og á auðveldara með að komast inn í leik.

Stundum velja börn sér einveru, eru sjálfum sér nóg og una sér vel án pess að vera í samskiptum við önnur börn. Í öðrum tilfellum er barni hafnað eða pað hunsað af öðrum börnum. Að vera hafnað felur í sér að barnið fær ekki hlutdeild í hópnum og er haldið markvisst utan hans en ef pað er hunsað er pað látið afskiptalaust. Í sumum tilfellum er hægt að tengja höfnun barns við hegðun pess, svo sem ef pað sýnir árásargirni, stjórnsemi eða er truflandi í leik (Dunn, 2004).

\section{Vina- og félagatengsl barna af erlendum uppruna}

Erlendar rannsóknir sýna að barn velur sér frekar náinn vin af sama pjóðerni og pað sjálft er og að með hækkandi aldri eykst pessi tilhneiging (Graham, Taylor og Ho, 2009). Vinatengsl milli barna af sama uppruna tengist betri líðan (McGill, Way og Hughes, 2012) og skapar tækifæri til stuðnings og aðstoðar (Suárez-Orozco, Suárez-Orozco og Todorova, 2009). Á hinn bóginn kemur fram að vinátta barna og unglinga pvert á pjóđerni getur unnið gegn fordómum gagnvart öðrum pjóðernishópum (Pettigrew og Tropp, 2008). Álykta má að fyrir barn af erlendum uppruna sé best að eiga vináttusambönd af báðum gerðum, pað er innan eigin hóps og við börn af ólíkum uppruna. Ásamt fjölmenningarlegum kennsluháttum sem felast til dæmis í fjölbreyttum námsaðferðum (Banks, 2010), stuðla tengsl bæði innan hóps og milli hópa að pví að barninu finnist pað tilheyra hópnum og upplifir sig síður einmana (Graham, Munniksma og Juvonen, 2014).

Ekki hafa verið gerðar rannsóknir hér á landi á vinatengslum leikskólabarna af erlendum uppruna. Rannsóknir meðal eldri barna og unglinga benda pó til að á brattann sé að sækja. Nína V. Magnúsdóttur (2010) komst að pví að pað reyndist unglingum af erlendum uppruna torsótt að eignast íslenska vini pó pað pætti eftirsóknarvert. Menningarmunur virtist skýra pennan vanda og var pað áhugavert að aukin kunnátta í íslensku ein og sér dugði peim ekki til pess að eignast íslenska vini. Hrefna Guðmundsdóttir og Hanna Ragnarsdóttir (2013) greindu vinatengsl barna 1 5.-7. bekk út frá móðurmáli sem var talað heima. Fram kom að 13,5\% barna par sem eingöngu annað mál en íslenska var töluð, áttu enga eða fáa vini en petta átti við um 6,9\% barna par sem íslenska var töluð heima. Að sama skapi var sjaldgæfara að börn af erlendum uppruna hittu vini eða vinkonur eftir skólann eða um helgar. Algengara var að fyrrnefndi hópurinn upplifði stríðni og að vera skilinn út undan. Aðrar rannsóknir benda til pess að líkur á pví að verða fyrir einelti aukist eftir pví sem litarháttur og menningarheimur er ólíkari íslenskri menningu (bóroddur Bjarnason, 2006). Í samanburði við íslenska jafnaldra fannst minni lífsánægja og meiri vanlíðan hjá ungmennum af pólskum og asískum uppruna í 6., 8. og 10. bekk en félagslegur stuðningur, efnahagsstaða og fjölskyldugerð tengdist líðan (Eyrún María Rúnarsdóttir og Rúnar Vilhjálmsson, 2015).

Rannsóknir meðal barna af erlendum uppruna á grunnskólaaldri gefa til kynna að pau séu líklegri til að verða fyrir pola höfnun og jafnvel einelti. Pau búa ekki heldur við vernd frá vinum að sama skapi og íslensk börn. Ástæða er til að ætla að sambærileg mynstur sé að finna meðal yngri barna og er mikilvægt að fá úr pví skorið. 


\section{Leikskólastarf, skólamenning og heimamenning}

Aðalnámskrá leikskóla (Mennta- og menningarmálaráðuneytið, 2011) er ígildi reglugerðar og par segir að leikskólinn eigi að vera samfélag par sem einstaklingur nýtur virðingar. Starf leikskólans á að byggja á jafnrétti, virðingu fyrir margbreytileika mannlífsins og öðrum menningarheimum. Jafnframt á leikskólinn að hafa að leiðarljósi að réttur allra barna sem par dvelja sé virtur óháð bakgrunni peirra, aðstæðum eða getu. Leitast skal við að koma til móts við parfir allra. Баð er bví margt í aðalnámskránni sem hefur beina tilvísun til barna af erlendum uppruna. Dar kemur einnig fram að efla purfi færni barna í samskiptum, styrkja sjálfsmynd peirra og stuðla að félagslegum tengslum, próun samkenndar, tillitssemi og vináttu.

Fram kemur í Aðalnámskrá leikskóla (Mennta- og menningarmálaráđuneytið, 2011) að allir skólar eigi að vinna með hugmyndafræði skóla án aðgreiningar. Í stuttu máli pýðir bað að skipulagt skólastarf aðgreinir ekki nemendur í sérstaka skóla, deildir eða bekki eftir fötlun, uppruna eða námsgetu, heldur leitast við að gefa öllum nemendum sama rétt til náms og stuðla að fullri og virkri pátttöku peirra í skólasamfélaginu (Berglind Rós Magnúsdóttir, 2016). Dví tengt er hugtakið fjölmenningarlegir kennsluhættir. Banks (2010) skilgreinir fjölmenningarlega kennsluhætti á pann hátt að par sé byggt á ólíkum námsleiðum og aðferðum sem komi til móts við fjölbreyttan nemendahóp. Leiðarljós sé að allir nemendur hafi sömu tækifæri til menntunar óháð kyni, félagslegri stöðu, uppruna eða menningu. Hann bendir á að varast beri að byggja fjölmenningarlega kennsluhætti á sérstöđu og staðalímyndum en í rannsóknum sínum hefur hann komist að pví að slíkir kennsluhættir geti ýtt undir fordóma og staðlaðar hugmyndir hjá börnum. Pá er hlutverk sérkennara og leikskólakennara ekki að greina námsörðugleika barna og takmarkanir heldur að útfæra og laga námskrá og kennslu að pörfum allra nemenda (Ferguson o.fl., 2012).

Íslenskar rannsóknir benda til að ekki takist alltaf að vinna samkvæmt ofangreindri stefnu. Í langtímarannsókn Hönnu Ragnarsdóttur (2010) í íslenskum leikskólum kom fram að skipulag og pekkingu skorti til að hægt væri mæta pörfum barna og hinum fjölmenningarlega veruleika nægilega vel. Upplýsingagjöf til foreldra af erlendum uppruna var af skornum skammti og pví skorti á gagnkvæman skilning á milli foreldra og starfsfólks skóla. Pá benda niðurstöđur Láru Jónu Dorsteinsdóttur (2008) til pess að foreldrar grunnskólabarna af erlendum uppruna séu utangátta í foreldrasamstarfi skóla og rannsókn Póru Bjarkar Ágústsdóttur (2008) sýndi lítinn samgang milli foreldra af erlendum uppruna og íslenskra foreldra.

Staða barna af erlendum uppruna við upphaf grunnskólagöngu er almennt verri en staða jafnaldra peirra, par sem pau skortir íslenskukunnáttu til að eiga samskipti við jafnaldra sína og tileinka sér námsefnið (Hanna Ragnarsdóttir, 2004). Í rannsókn Brooker (2002) á gengi 16 fjögurra ára barna í breskum skóla kom fram að börn sem komu frá ríkjandi menningu par sem heimamenning og skólamenning var ápekk höfðu forskot á önnur börn. Dau áttu auðveldara með að nálgast skólaverkefni og gátu nýtt úrræði og áhöld sem purfti til pess að leysa verkefni. Eftir pví sem munur var meiri á heimamenningu og skólamenningu reyndist peim erfiðara að skipta á milli pessara tveggja menningarheima. Ríkur skilningur á pýðingu ólíkrar menningar á heimili og í skóla er pví einn lykilpátta pess að ungum börnum af erlendum uppruna farnist vel, en annar lykilpáttur er tungumálið.

Börn af erlendum uppruna sem hafa ekki náð aldurssamsvarandi valdi á íslenskri tungu eru að vissu leyti í sambærilegri stöðu og börn sem ekki eru farin að tjá sig í töluðu máli. Hrönn Pálmadóttir og Jóhanna Einarsdóttir (2012) komust að pví að síðarnefndi hópurinn hafði færri tækifæri en pau börn sem eldri voru til pess að hafa áhrif í leikskólasamfélaginu. Gera má ráð fyrir að petta eigi einnig við um hluta barna af erlendum uppruna. Hætta er á að pau eigi erfitt með að fóta sig 1 frjálsa leiknum og lendi í árekstrum sem pau kunna ekki að leysa úr. Í pessu samhengi er áhugavert að skoða viðhorf leikskólakennara til íhlutunar í frjálsum leik barna og í hópastarfi en Hrönn Pálmadóttir (2004) gerði pað í rannsókn sinni. Par kom fram að íhlutun í frjálsum leik barna ætti að vera sem minnst og leikurinn alfarið á forsendum barna. 
Ríkar skyldur eru lagðar á herðar leikskólakennara að finna leiðir til að virkja börn af erlendum uppruna í leikskólasamfélaginu. Ađalnámskrá leikskóla (Mennta- og menningarmálaráðuneytið, 2011) kveður skýrt á um að skólum á öllum skólastigum beri að vinna með jafnrétti og lýðræði að leiðarljósi. Mikilvægt er að styðja boðskipti og samskiptahæfni barna af erlendum uppruna enda er pað undirstaða pess að mynda félagsleg tengsl og vináttu. Á pað ekki síður við í frjálsa leiknum en í skipulögðum kennslutímum.

Rannsóknin sem hér er kynnt hafði pann tilgang að auka skilning á félagslegum tengslum, vináttu og samskiptum leikskólabarna af erlendum uppruna í pví skyni að draga fram hvers konar hindrunum pau geta mætt og hvernig bæta megi stöðu peirra í jafningjahópnum. Markmiðið var að varpa ljósi á félagsleg tengsl barnanna með eftirfarandi rannsóknarspurningar að leiðarljósi: Hvernig upplifa börn af erlendum uppruna félagsleg tengsl sín og vináttu við jafnaldra? Hvernig birtast tengsl barnanna við önnur börn? Hvað hvetur til jákvæðra tengsla og samskipta barna af erlendum uppruna við jafnaldra og hvað stendur helst í vegi fyrir slíkum tengslum? Vonast er til að aukinn skilningur á félagslegum tengslum barnanna verði til pess að hægt sé að grípa betur inn í og styðja börnin par sem stuðningur kemur sér best.

\section{Aðferð}

Eigindlegri rannsóknaraðferð var beitt í rannsókninni. Aðferðin býður upp á fjölbreyttar leiðir til að skoða upplifanir og reynslu barna og að kanna samspil ólíkra pátta (Jóhanna Einarsdóttir, 2007). Gögnum var safnað með hópviðtölum, einstaklingsviðtölum, myndbandsupptökum, teikningum og ljósmyndum barna ásamt að pau voru beðin um að svara tengslakönnun og útbúa vináttuvef. Markmið með eigindlegri rannsókn sem pessari er ekki að alhæfa og yfirfæra niðurstöður yfir á öll börn af erlendum uppruna á leikskólaaldri heldur ber að líta svo á að rannsóknin veiti innsýn í stöðu pessara barna á Íslandi.

\section{Dátttakendur}

Úrtakið er tilgangsúrtak en í pví felst að rannsakandinn velur úrtak með parfir og markmið rannsóknarinnar í huga. Valdir eru einstaklingar sem hafa mikla pekkingu og reynslu af pví efni sem rannsaka á og geta par með gefið pær upplýsingar sem leitað er eftir í rannsókninni (Flick, 2006). Rannsóknin fór fram í fjögurra deilda leikskóla sem staðsettur er í kauptúni á landsbyggðinni. Á deildinni voru 21 barn, 11 strákar og 10 stelpur fædd 2009-2011 sem tóku pátt 1 rannsókninni að einhverju leyti. Alls voru sex börn af erlendum uppruna á deildinni en lykilpátttakendur voru fjórir, tvær stelpur og tveir strákar. Hefur nöfnum allra barnanna á deildinni verið breytt.

Lykilbörnin fjögur voru fædd árið 2009 og voru öll á aldrinum 5-6 ára, á síðasta ári í leikskólanum, pegar rannsóknin fór fram. Foreldrar tveggja barna voru frá Póllandi og hinna tveggja frá Tælandi. Móðurmál foreldranna var talað á heimili barnanna og voru börnin tvítyngd. Börnunum fjórum voru gefin gervinöfnin Daniel, Stefan, Alexandra og Sara. Daniel og Alexandra koma frá Póllandi en Daniel fæddist par og flutti til Íslands með móður sinni vorið 2013. Alexandra er fæedd á Íslandi en fluttist nokkurra mánaða gömul til Póllands par sem hún bjó til ársins 2012. Pá flutti hún til Íslands aftur og hóf leikskólagöngu á Íslandi. Sara og Stefan eru fædd á Íslandi. Stefan bjó um skeið í Tælandi en byrjaði í íslenskum leikskóla 2012. Sara byrjaði í leikskólanum 2011.

Rannsóknin fór fram á annarri deildinni af tveimur par sem elstu börnin dvelja. Deildinni er skipt upp í tvær einingar sem samanstanda af heimastofu og tveimur minni leikherbergjum. Börnin borða hvert í sinni heimastofu og eru hluta af degi aðskilin, meðal annars í hópastarfi, á matartímum og í hvíld. Dau hittast pó oft yfir daginn, til dæmis í samverustund og útiveru. Kennarar á deildinni eru fimm í mismunandi starfshlutföllum og par af einn starfsmaður sem sér um stuðning við eitt barn. Leikskólastjóri og kennarar á deildinni voru jákvæðir gagnvart rannsókninni, andrúmsloftið var jákvætt og rannsakandanum var vel tekið. 


\section{Framkvæmd}

Upplýsts sampykkis var aflað frá pátttakendum, foreldrum, starfsfólki leikskólans og yfirmanni skólamála í sveitarfélaginu. Rannsóknin var kynnt efnislega í bréfi til leikskólastjóra og kennara og á fundi með starfsfólki. Skriflegt sampykki fyrir rannsókninni var fengið frá leikskólastjóra og yfirmanni skólamála í sveitarfélaginu. Rannsóknin var kynnt fyrir öllum foreldrum á deildinni með bréfi í tölvupósti og gáfu allir skriflegt sampykki fyrir pátttöku.

Rannsóknin var sérstaklega kynnt fyrir foreldrum lykilbarnanna fjögurra í einstaklingssamtali með rannsakanda. Dar voru markmið rannsóknar og framkvæmd útskýrð. Íslenskukunnátta foreldranna var misjöfn og pví var túlkur með í pessum viðtölum. Foreldrar barnanna tóku beiðninni vel og voru allir tilbúnir til að gefa skriflegt leyfi sitt fyrir pátttöku barna peirra í rannsókninni. Rannsóknin var tilkynnt til Persónuverndar.

Sampykkis lykilpáttakenda var aflað eftir tvo fundi með peim. Á fyrsta fundi kynntist rannsakandi börnunum til að byggja upp traust. Spjallað var um veru rannsakandans á staðnum, rannsóknina og hlustað eftir sjónarmiðum barnanna. Á öðrum fundi voru markmið rannsóknar rifjuð upp og pess gæett að börnin skildu að pau pyrftu ekki að taka pátt ef pau vildu pað ekki. Óskað var eftir skriflegu sampykki frá börnunum með blaði með broskalli og fýlukalli. Börnin fengu fyrirmæli um að lita broskallinn ef pau vildu taka pátt en fýlukallinn ef pau vildu ekki taka pátt og loks að skrifa stafinn sinn á blaðið. Öll börnin lituðu broskallinn og settu stafinn sinn á blaðið. Munnlegt sampykki var fengið hjá hverju og einu barni (hvort sem um var að ræða lykilpátttakendur eða önnur börn) í hvert sinn pegar myndbandsupptaka var gerð af frjálsum leik barnanna.

\section{Gagnasöfnun}

Gagnasöfnun fór fram í maí 2015. Tekin voru hópviðtöl í tvígang við lykilpátttakendurna fjóra og tvö paraviðtöl; eitt við drengina saman og annað við stúlkurnar saman. Eitt einstaklingsviðtal var tekið við hvert barn eða alls fjögur einstaklingsviðtöl. Viðtöl voru hálfopin og var spurningarammi hafður til hliðsjónar. Í seinna hópviðtali teiknuðu börnin sig og besta vin sinn og var spjallað um myndirnar. Fyrir einstaklingsviðtölin höfðu börnin myndavélar í einn dag í leikskólanum og tóku myndir af vinum sínum og pví sem peim fannst áhugavert í leikskólaumhverfinu. Í einstaklingsviðtölum stjórnuðu myndirnar umræðuefninu og pannig stýrði hvert barn yfirferð í sínu viðtali. Lengd viðtala var um 30-40 mínútur. Viðtölin voru hljóðrituð og einnig tekin upp á myndband. Að lokum var hvert viðtal afritað orð fyrir orð.

Alls voru gerðar 11 myndbandsupptökur og samhliða ritaði rannsakandi vettvangsnótur á staðnum. Lengd myndbandsupptaka var að jafnaði um 10 mínútur. Myndbandsupptökur voru teknar í frjálsum leik og við daglegar athafnir af aðstæðum par sem lykilbörn í rannsókninni voru pátttakendur ásamt öðrum börnum. Pegar heim var komið voru upptökurnar skoðaðar og afritaðar orð frá orði.

Tengslakönnun var lögð fyrir öll börnin á deildinni og vináttuvefskönnun fyrir lykilpátttakendurna fjóra. Í tengslakönnun var myndum af öllum börnunum á deildinni raðað á borð og hvert barn valdi mynd af besta vini sínum í leikskólanum. Könnunin gerði kleift að kortleggja hvort um gagnkvæm vinatengsl var að ræða og hvernig staða barna af erlendum uppruna var í hópnum. Daniel, Sara, Stefan og Alexandra bjuggu til vináttuvef með pví að setja mynd af sjálfu sér í miðjuna og áttu síðan að raða eins mörgum vinum og pau vildu í kringum sig.

Rannsakandi hélt rannsóknardagbók á meðan gagnasöfnun stóð yfir par sem skráðar voru hugleiðingar af vettvangi. Í dagbókinni er hægt að sjá ferli rannsóknarinnar, riss, nótur og pað sem vakti áhuga við lestur eða gagnaöflun. 


\section{Gagnagreining}

Í greiningarferlinu var leitað eftir pemum, lykilorðum, endurtekningum, andstæðum og samstæðum í gögnunum með opinni lyklun. Dá voru kóðarnir flokkaðir saman og pannig mynduðust pemu. Bogdan og Biklen (2007) benda á að pessi leið auki dýpt rannsóknargagnanna og hjálpi við að draga fram pemu úr peim. Við lyklun komu fram meginpemun samskipti, vinátta, að eignast vini, hamlandi pættir og útilokun. Gögnin voru síðan lesin yfir aftur og aftur, lykluð að nýju og í lokin notast við öxullyklun til að leita eftir tengslum milli atriða og setja pau í samhengi. Öxullyklun byggist á að skoða kóðana á kerfisbundinn hátt með pví að koma auga á tengingar á milli kóða og pema. Tilgangurinn er að finna samhengi, orsakir og afleiðingar (Bogdan og Biklen, 2007).

Að lokum voru dregin fram prjú pemu sem fjallað verður um en pau eru vinátta og félagsleg tengsl, áhugamál, leikur og samskipti og að lokum tungumál, heimamenning og skólamenning. Í beinum tilvitnunum stendur $\mathrm{R}$ fyrir rannsakanda.

\section{Niðurstöður}

\section{Vinátta og félagsleg tengsl}

Í samtölum við Alexöndru, Söru, Stefan og Daniel voru pau öll sammála pví að vinir leika sér saman og að pað geri pá að vinum. Dau sögðu að vinir gerðu bara allt saman, nefndu að peir lékju sér saman inni og úti og allt frá pví að vera saman í Ipad eða leika saman í sandkassanum. Börnin höfðu mótaðar skoðanir á pví hverjir væru vinir í leikskólanum og hverjir ekki og nokkrum sinnum kom fram í samtali að ákveðin börn voru ekki vinir peirra. Börnin sögðu að pegar maður vildi eignast vin pá spyrði maður krakkana hvort peir vildu verða vinir sínir. Alexandra vildi eiga marga vini og sagðist oft spyrja: „Ég líka búin að spyrja, ég alltaf búin að spyrja ... pá segir maður nei eða já." Hún pekkti pað að fá stundum neitun en stundum jákvætt svar.

Birtingarmynd vináttu var með ýmsu móti hjá börnunum. Meðal ljósmynda sem Daniel tók var ein mynd af tveimur drengjum að faðmast. Hann útskýrði myndina:

$$
\begin{aligned}
& \text { R: Af hverju eru peir að knúsast? } \\
& \text { D: Deir eru vinir. } \\
& \text { R: En af hverju eru peir vinir? } \\
& \text { D: Deir leika saman og eru glaðir, pað er bara svo gott. }
\end{aligned}
$$

Vináttan var pví uppspretta gleði, ánægju og vellíðunar og var áberandi víðar að gleði og vinátta tengdust í huga barnanna. Degar Stefan sagði frá myndunum sem hann tók á myndavélina hló hann innilega að mynd af vini sínum. Hann sagði: „Hann er að gera eitthvað bull.“ Degar hann var spurður áfram um myndina var hann á pví að vinir gerðu stundum eitthvað bull sem er fyndið.

Börnin voru sammála pví að eitt af pví sem vinir gera er að hjálpa ef einhverjum líður illa eða hefur meitt sig. Í pví fólst að börnin sýndu öđrum börnum samkennd og umhyggju. Alexandra kom með dæmi: „Ég búin hjálpa Veru gráta, Martin var meiddi ... ég hjálpa Veru.“ Stefani var einnig umhugað um hin börnin, sérstaklega var pað áberandi gagnvart Söru. Detta kemur skýrt fram í einu myndbandinu par sem Stefan, Daniel og Sara eru að leika með holkubba. Daniel kastar einum kubbi frá sér pannig að hann lendir nálægt Söru: 
St: Neiiiii. (Hrópar upp og horfir á Söru en kubburinn lendir nálægt henni).

St: Sjáðu Daniel. (Horfir á Söru og Daniel til skiptis og er brugðið).

St: Fór petta á pig Sara? (Stefan færir sig til Söru og athugar hvort hún hafi meitt sig).

Stefan nefndi að vinir knúsuðu hvor annan pegar einhver meiddi sig og að ef maður gerði eitthvað á hlut vinar síns pá segði maður fyrirgefðu og faðmaði viðkomandi. Баð kom einnig fram í samtali við Stefan að vinir ættu stundum leyndarmál saman sem aðrir vissu ekki af.

Öll fjögur börnin áttu vini í leikskólanum en pegar teknar eru saman niðurstöður úr tengslakönnun og vináttuvef kemur fram að pau höfðu mismunandi stöðu í barnahópnum:

- Stefan var valinn fimm sinnum í tengslakönnun en aðeins eitt annað barn var valið svo oft. Hann bjó við gagnkvæm vinatengsl og valdi marga vini í vináttuvef sinn. Petta bendir til sterkrar stöðu og að hann hafi upplifað sig sem virkan pátttakanda í barnahópnum.

- Daniel var einn af sex börnum sem var valinn tvisvar, hann var pó aldrei valinn sem fyrsti kostur og aldrei var um gagnkvæm tengsl að ræða. Hann valdi marga vini í vináttuvef sinn en pað bendir til pess að hann upplifði sig ekki einangraðan og hafði væntingar um að vera virkur pátttakandi í hópnum.

- Alexandra var valin einu sinni eins og fimm önnur börn. Hún var valin sem fyrsti kostur og par má sjá gagnkvæm vinatengsl. Ætla má að hún hafi átt traustan besta vin í leikskólanum en hún var valin af stúlku sem er af sama pjóðerni og hún sjálf. Hún valdi marga vini í vináttuvef sinn sem bendir til að hún hafi upplifað sig virkan pátttakanda eða að hún vilji vera virkur pátttakandi í hópnum.

- Sara var einnig valin einu sinni. Hún var valin sem fyrsti kostur og bjó við gagnkvæm tengsl sem bendir til pess að hún hafi átt traustan vin í leikskólanum. Hún valdi einungis einn vin í vináttuvef sinn sem má túlka pannig að hún upplifi sig ekki sem hluta af hópnum og/eða hafi ekki löngun til pess að tilheyra honum.

Alexandra var sú eina sem valdi eingöngu vini af sama pjóðerni en pjóðernið virtist ekki hafa áhrif á val hinna priggja. Hún er einnig sú eina sem valdi barn af öðru kyni. Öll börnin bjuggu annaðhvort við gagnkvæm tengsl eða völdu marga vini í vef sinn. Dau sýndu skilning á pýðingu og mikilvægi vina og vildu eiga vini. Fleira skiptir pó máli pegar kemur að stöðu í barnahópi og pví beinist athyglin næst að áhugamálum, leik og samskiptum barna í leikskólanum.

\section{Áhugamál, leikur og samskipti}

Alexandra talaði um að sér fyndist skemmtilegast að lita og að róla með Veru, vinkonu sinni. Söru fannst einnig skemmtilegt að róla og skemmtilegast í dekkjarólunni pví að í henni gat hún rólað með Guðmundu, vinkonu sinni. Stefan var mikið fyrir að vera úti, fannst hópleikir sem byggjast á hreyfingu skemmtilegastir og nefndi stórfiskaleik og fótbolta. Einnig fannst honum skemmtilegt að hjóla og róla. Daniel talaði um að honum fyndist allt skemmtilegt í leikskólanum en síðan nefndi hann að hann elskaði byssó, líka zombie og Star Wars.

Börnin höfðu mismunandi færni við að komast inn í leik. Stefan var klár að lesa í leikinn, fylgjast með og setja sig inn í hann. Í myndböndum má sjá að hann notaði bæði yrt og óyrt boðskipti til pess. Einnig mátti sjá að létt lundarfar hans hjálpaði honum og hversu stutt var í grínið. Hann var áhugasamur um leikinn, hafði góða nærveru og samskipti við leikfélaga voru góð. Alexandra, Daniel og Stefan notuðu stundum pá aðferð að reyna að vera sniðug og fyndin til pess að komast inn í leikinn og fá athygli. Leikur allra barnanna einkenndist af ærslagangi nema leikur Söru sem valdi rólega leiki. Lítil munnleg samskipti einkenndu leik allra barnanna fjögurra.

Áberandi var að Sara fylgdist með leiknum en reyndi ekki að komast inn í hann. Hún var á hliðarlínunni og virtist samt hafa aðgang að leikjum ef hún óskaði sér pess. Í myndböndum af 
Söru var hún talsvert til baka í samskiptum sínum við hin börnin og virtist ekki tala mikið við pau. Hún fylgdist pó vel með pví sem var að gerast í kringum sig og veitti hinum börnunum athygli. Hún virtist eiga góð samskipti við hin börnin og lenti ekki í árekstrum við pau meðan á gagnasöfnun stóð. Sara og Guðmunda, besta vinkona Söru höfðu heimsótt hvor aðra eftir skóla. Guðmunda er íslensk og pví var fróðlegt að fylgjast með samskiptum peirra, par sem íslenskukunnátta Söru var nokkuð takmörkuð. Dær völdu sér rólega borðleiki og töluðu saman í hálfum hljóðum.

Daniel sótti í að vera í hasarleikjum við krakkana og peim fylgdi oft mikill hávaði og læti. Hann var nokkuð ör í samskiptum, virtist eiga erfitt með að setja sig inn í leikinn og fylgja leikreglum. Áhugi Daniels á pessari tegund af leikjum var gegnumgangandi í myndböndum og samtölum. Daniel lenti nokkuð oft 1 átökum við önnur börn og stundum meiddist einhver í leikjum sem hann tók pátt í.

Alexandra var áhugasöm um hvað önnur börn aðhöfðust. Hún sýndi leik stráka mikinn áhuga en virtist ekki hafa pá færni sem purfti til pess að komast inn í leik peirra og fékk sjaldnast aðgang að honum. Í eftirfarandi lýsingu á upptöku voru fimm börn í leik saman; Stefan, Porgrímur, Hjörleifur, Alexandra og Arndís. Pau léku sér saman að holkubbum og voru ein inni í kubbaherberginu. Kennari kom við og við inn í herbergið til að fylgjast með leiknum:

Allir krakkarnir eru að leika með holkubbana og eru að byggja úr peim nema Alexandra sem bara horfir á pað sem börnin eru að gera. Hún sniglast í kringum pau og fylgist vel með pví sem strákarnir eru að gera en veitir pví ekki athygli sem Arndís er að gera. Alexandra reynir að komast inn í leikinn, sem strákarnir eru í, með pví að leika hund fyrir framan pá. Deir veita henni enga athygli og stuttu seinna hættir hún aơ leika hundinn.

Alexandra á í góðum samskiptum við vinkonu sína Veru. Gott flæði er í leik peirra og pær eru jafningjar par sem báðar koma með tillögur í leikinn. Hér teljum við skipta miklu máli að Alexandra hefur tök á pví að tala sitt móðurmál í leiknum, samskiptin á milli stelpnanna eru ópvinguð og leikurinn rólegur og yfirvegaður. Hins vegar bar á skorti á einbeitingu hjá Alexöndru og um leið og eitthvað heyrðist í stofunni fyrir framan pá hætti hún að leika og fór að hlusta, ólíkt Veru sem hélt áfram í sínum leik.

Fram komu dæmi um hlutverk barna í leik par sem hallaði á börnin sem voru af erlendum uppruna. Pá urðu pau fyrir höfnun og hunsun í leiknum, áttu erfitt með að koma skoðun sinni á framfæri og hvorki var hlustað á pau né tekið tillit til pess sem pau höfðu að segja. Einnig sáust merki um að pau einangruðu sig úr hópnum, áttu kannski einn vin eða leituðu eftir vináttu í fámennum hópi eftir pjóðerni. Lykilbörnin fjögur; Alexandra, Stefan, Sara og Daniel urðu pó ekki verst úti að pessu leyti og vakti athygli hversu erfið staða Martins, sem er af pólskum uppruna, var. Áberandi var hversu neikvæð lykilbörnin í rannsókninni voru gagnvart honum.

Dæmi voru um að leik væri stillt upp pannig að tveir væru á móti einu barni, góðu á móti vonda, og pað var vel passað upp á að Daniel væri sá vondi. Detta mátti glöggt sjá í einu myndbandinu par sem Daniel er í ofurhetjuleik með tveimur íslenskum strákum. Daniel verður fyrir útilokun í leiknum, en annar strákurinn reynir markvisst að stilla leiknum pannig upp að peir tveir séu saman í liði á móti Daniel. Niðurstöður virðast pó benda til pess að börnin hafi ekki alltaf gert sér grein fyrir pví að peim væri hafnað eða pau hunsuð af jafningjum eða að leikurinn væri ekki á jafnréttisgrunni. Löngunin til að fá að vera pátttakandi var svo sterk að pau virtust láta ýmislegt yfir sig ganga. Dó voru dæmi um að pau létu kennara vita ef barn meiddi aðra eða fór ekki eftir reglum. Dau virtust pó síður láta vita ef pau voru hunsuð eða fengu ekki að vera pátttakendur í leik.

Athygli vakti hvernig Stefan brást við pegar tillögur hans í leik fengu lítinn sem engan hljómgrunn. Leið hans var að tala stöðugt um hvað hann ætlaði sér að gera og má velta pví fyrir sér hvort hann hafi verið að kanna hvort tillögur hans yrðu sampykktar. Í myndbandsbroti einu fékk 
Stefan sex sinnum nei við tillögum sem hann kom með, hann var hunsaður nokkrum sinnum og honum ekki svarað. Hins vegar var Stefan mjög vinsæll miðað við niðurstöðu tengslakönnunar. Jafnaðargeð hans virtist pví vinna bæði með honum og á móti. Hann átti marga vini pví hann var alltaf jákvæður, klár og pægilegur í samskiptum en hins vegar vantaði að hann stæði á sinni skoðun gagnvart vinum.

Öll börnin fjögur voru á peirri skoðun að ekki væri fallegt að skilja út undan eða að stríða öðrum. Ekkert peirra kannaðist við að hafa gert pað. Hins vegar leiddi rannsóknin í ljós að pau tóku pátt í pví að hafna eða útiloka önnur börn á einn eða annan hátt. Á myndbandsupptöku sást Stefan hæðast að Daniel og hann tók pátt í að halda ákveðnum börnum frá leiknum með hunsun eða beinum orðum.

\section{Tungumál, heimamenning og skólamenning}

Tungumálið er eitt af lykilatriðum í samskiptum barna og pað kom skýrt fram á vettvangi að slök íslenskukunnátta barnanna fjögurra hafði áhrif á leikinn. Leikur peirra var fremur yfirborðslegur og byggðist lítið á munnlegum samskiptum en pess í stað var meira um handahreyfingar og hasarleiki. Pau áttu erfitt með að rökræða og standa á sinni skoðun og bökkuðu frekar með hugmyndir sínar til pess að koma í veg fyrir átök. Undantekning á pessu var pó pegar Alexandra lék sér með Veru en pá gátu pær báđar notað móðurmál sitt í leiknum. Tælenska var ekki notuð sem tungumál hjá börnunum sem voru af tælensku bergi brotin, líkt og hjá pólsku börnunum. Málsamfélag tælensku barnanna var lítið, einungis tvö börn í leikskólanum höfðu tælensku að móðurmáli og enginn starfsmaður talaði tælensku. Til samanburðar töluðu fjögur börn pólsku í leikskólanum og einn kennari.

Degar Stefan og Daniel voru spurðir hvaða tungumál peir töluðu saman pegar peir væru að leika sér sögðust peir tala saman á íslensku. Í umræðu um tungumál var Daniel spurður hvort hann talaði pólsku í leikskólanum. Stefan var fljótari að svara spurningunni:

St: Já, alltaf.

D: Já, Martin, Alexandra og Vera.

R: Hvort finnst pér betra að tala pólsku eða íslensku í leikskólanum?

D: Gott að tala pólsku.

Degar Daniel var spurður hvort honum fyndist gott að vera í leikskólanum var svarið neitandi. Ástæðan sem hann gaf var eftirfarandi:

D: Kennarinn tala svona íslensku.

R: Skilur pú allt sem kennarinn segir?

D: Bara pínulítið af.

R:Viltu skilja allt sem kennarinn segir?

D: Já.

Börnin fjögur vildu segja frá og ræða uppruna sinn. Dau buðu rannsakanda í heimsókn og með sér til heimalandsins. Pau nutu pess að spjalla um móðurmál sitt, fannst spennandi að rannsakandi kynni orð á móðurmáli peirra og vildu kenna fleiri orð. Stefan nefndi samt að hann gæti ekki kennt alla tælenskuna par sem hann kynni hana ekki alveg. 
Í viðtölum við börnin kom í ljós að pað skipti pau miklu máli að fá að bjóða vinum heim eftir skólann og geta kynnt peim heimamenningu sína, leikið með dótið sitt með vinum sínum, sýnt herbergið sitt og heimili. Pau töluðu um hverjir hefðu komið heim til peirra og hvaða vinir hefðu boðið peim heim til sín. Að bjóða börnum heim var jafnvel notað sem skiptimynt eða hótun til að fá eitthvað frá öđrum: „Dú mátt ekki koma heim til mín nema ég fái bílinn sem pú ert með,“ sagði Daniel. Stefan sagðist oftast hitta vini sína eftir leikskólann.

Hins vegar kom fram að sum börnin höfðu ekki sömu tækifæri til pess að deila heimamenningu sinni með vinum úr leikskólanum. Í samtali við leikskólakennara kom fram að Daniel hefði lítil samskipti við leikskólafélagana utan leikskólans. Hann sagði frá pví að mamma hans leyfði honum ekki að bjóða vinum heim og útskýrði:

D: Mamma mín ekki segja mér, ég má fara til vinur upp, ég má ekki fara til vinur mín upp.

R: Máttu ekki fara til vinar píns sem býr uppi?

D: Nei, en ég má fara út að leika við vini og vinur.

Баð var greinilegt að hann var ekki sáttur við pessa ákvörðun hennar en sagði hins vegar frá heimsóknum til tveggja pólskra barna með móður sinni. Stefan virtist meðvitaður um pað að Daniel mætti ekki leika eftir skólann og sagði frá pví í viðtali við rannsakanda að Daniel léki mikið einn og að móðir hans leyfði honum ekki að heimsækja sig.

Eins og ádur hefur komið fram lenti Daniel stundum í átökum við önnur börn í leiknum. Vera má að parna hafi árekstur heimamenningar og skólamenningar átt hlut að máli. Daniel og Stefan sögðu frá:

St: Daniel er alltaf að meiða.

D: Nei. Allir ýta mig.

R: Hvað gerir pú pá? (Stefan var fyrri til og svaraði með pví að tilgreina hvaða reglur giltu í leikskólanum).

St: Segja bara hættu en ef maður hættir ekki pá verður maður að segja kennara.

R: En hvað gerir pú Daniel?

D: Mín mamma segir að ef einhverjir krakkar ýta mér, pá ég gera hviss, hviss, hviss, hættu pessu, hviss, hviss, hviss (gerir hreyfingar með pessu eins og hann sé að slást).

Daniel notaði rád mömmu sinnar í leikskólanum sem fólust í að hann ætti að slást á móti ef einhver ýtti í hann eða meiddi. Dessi leið var ekki viðurkennd í leikskólanum líkt og Stefan útskýrði. Petta varð til pess að börnin litu svo á að hann væri alltaf að ráðast á pau og meiða.

Баð fylgdu pví áskoranir fyrir Daniel, Stefan, Alexöndru og Söru að vera tvítyngd í íslenskum leikskóla. Prátt fyrir að vinatengsl væru til staðar og börnin væru virk í samskiptum og leik mátti greina viðkvæma stöðu peirra af pessum ástæðum.

\section{Umræða}

Markmið rannsóknarinnar var að öðlast innsýn í félagsleg tengsl, vináttu, samskipti og leik leikskólabarna af erlendum uppruna. Með pví var ætlunin að öðlast skilning á pví hvað getur stutt við stöðu peirra í barnahópi, aukið vellíðan og öryggi. 
Ef skoðuð eru vinatengsl barnanna fjögurra standa pau misvel. Færa má rök fyrir pví að staða Daniels hafi verið slökust en staða Stefans sterkust. Lykilbörnin komu pó ekki verst út úr tengslakönnun enda voru prjú íslensk börn aldrei valin og pau bjuggu pví ekki við gagnkvæm vináttutengsl. Æskilegt væri að skoða stöðu pessara barna á deildinni nánar. Í tengslakönnun valdi Alexandra báđa vini sína af sama pjóðerni óháð kyni, sem samræmist pví sem kom fram hjá Graham, Taylor og Ho (2009) um tilhneigingu barna til að velja vini af sama uppruna. Stefan og Sara voru einu börnin með tælenskan bakgrunn en völdu ekki hvort annað sem vin. Ýmislegt benti til væntumpykju á milli peirra sem hægt væri að líkja við systkinavináttu. Stefan átti pað til dæmis til að tala fyrir Söru og útskýra pað sem hún ætlaði að segja. Рað má pví færa rök fyrir að börnin hafi getað sótt stuðning hvort til annars líkt og fram hefur komið í öðrum rannsóknum (McGill o.fl., 2012; Suárez-Orozco o.fl., 2009).

Vinátta var börnunum mikils virði og pau voru meðvituð um hverjir væru vinir peirra og hverjir ekki. Detta samræmist niðurstöðum um að frá fjögurra ára aldri sé pessi vitund fyrir hendi (Boivin, 2005). Vinatengslin virtust orðin nokkuð stöðug á milli barnanna en Bagwell og Schmidt (2011) benda á að eftir fjögurra ára aldur aukist stöðugleiki vinatengsla. Leikur og vinátta tengdust náið líkt og kemur fram í kenningum Bagwell og Schmidt (2011).

Samskipti reyndust mikilvæg en færni barna í að byggja upp tengsl við jafnaldra var mismunandi. Sum börnin voru klár að lesa í leikinn, fylgdust vel með honum og settu sig inn í aðstæður og samræmist pað kenningu Corsaro (2011) um að nokkra útsjónarsemi purfi til pess að komast inn í leik hjá öðrum börnum. Stefan, sem átti flesta vini, hafði góða færni í pessu, átti auðvelt með samskipti við börnin og lenti ekki í útistöðum. en hins vegar vantaði að hann stæði á sinni skoðun gagnvart vinum. Ef til vill má rekja pað til pess að íslenska er ekki móðurmál hans og að hann hafi ekki nægilegt vald á málinu til að rökræða við vini sína. Daniel notaði líkamstjáningu, handahreyfingar og ærslagang í leik. Í rannsókn Hrannar Pálmadóttur og Jóhönnu Einarsdóttur (2012) kom í ljós að handahreyfingar gegndu veigamiklu hlutverki hjá yngstu börnunum í leikskóla. Dær bentu á að pað gæti einnig átt við um eldri börn sem hefðu ekki pau tök á íslenskri tungu sem vænta mætti miðað við aldur. Alexandra virtist jafnframt vera spennt fyrir ærslafullum leik sem byggðist ekki á munnlegum samskiptum. Á hinn bóginn var hún virkust í leik pegar hún lék við Veru, pær voru báđar jafngildir pátttakendur og töluðu sitt móðurmál í leiknum. Draga má pá ályktun að íslenskan hafi verið hamlandi fyrir hana og haft áhrif á möguleika hennar á félagatengslum í leikskólanum en samkvæmt vináttuvef vildi hún eiga marga vini.

Eitt barn í rannsókninni skar sig að nokkru leyti úr hópnum. Dað var Sara en hún hafði nánast engin munnleg samskipti við krakkana nema pá við bestu vinkonu sína, Guðmundu. Prátt fyrir takmarkaða íslenskukunnáttu Söru áttu pær auðvelt með samskipti, völdu sér rólega borðleiki og töluðu saman í hálfum hljóðum. Dunn (2004) benti á að stundum væru börn mikið ein og að kennarinn pyrfti að fylgjast vel með peim börnum. Sum börn veldu sér petta hlutskipti sjálf og pau börn væru sjálfum sér nóg og yndu sér án mikilla samskipta við félagana.

Fram kom að börnin upplifðu pað sem hindrun að geta ekki tjáð sig eðlilega og ópvingað við önnur börn í leikskólanum. Tungumál var einnig hindrun í viðtölum, börnin skorti stundum pann orðaforða sem purfti til pess að segja frá og pau skildu ekki alltaf spurningar. Í peim aðstæðum vildu pau oft hætta að tjá sig. Tengsl íslenskukunnáttu og félagatengsla mátti til dæmis finna í pví að Stefan, sem var lengst kominn í íslensku, átti flesta vini. Hér verður einnig að hafa í huga hvað kemur á undan: Leiðir góð íslenskukunnátta af sér marga vini eða eykst færni í tungumáli í gegnum vinatengslin? Í rannsókn Nínu V. Magnúsdóttur (2010) kom fram að pó að íslenskufærni unglinga af erlendum uppruna styrktist leiddi pað ekki endilega til frekari tengsla við íslenska vini.

Tækifæri til að hitta önnur börn afleikskólanum utan skóla virtust hjá sumum barnanna takmarkast við vinahóp foreldranna sem voru af sama pjóðerni. Ef til vill er pað foreldrum af erlendum uppruna ekki eins tamt að bjóða börnum heim eftir skóla. Einnig getur verið munur á hvernig heimsóknir eru skipulagðar. Niðurstöður íslenskra rannsókna benda til pess að foreldrar erlendra 
barna séu í litlum samskiptum við íslenska foreldra (Dóra Björk Ágústsdóttir, 2008), pekki pá lítið og vilji ekki að börn peirra fari í heimsóknir til foreldra sem pau pekkja lítið. Einnig nefndu peir að íslenskir foreldrar væru lokaðir og erfitt væri að komast inn í hópinn (Hanna Halldóra Leifsdóttir, 2014). Við veltum pví fyrir okkur hvort æskilegt sé að leikskólinn hjálpi foreldrum af erlendum uppruna að mynda tengslanet við íslenska foreldra, láti foreldra vita að börn peirra leiki mikið saman í leikskólanum, kynni foreldrana hverja fyrir öðrum og stuðli að jákvæðu viðhorfi til vinatengsla sem hafa myndast pvert á pjóðerni. Kennarar ættu að hafa pað í huga að pað getur verið mikill munur á heimamenningu og skólamenningu barna af erlendum uppruna. Eftir pví sem munurinn er meiri reynist pað börnunum erfiðara að skipta á milli pessara menningarheima (Brooker, 2002). Раð er pví mikilvægt að kennarar byggi brú á milli menningarheima og séu tilbúnir að leiðbeina bæði börnum og foreldrum. Ríkur skilningur á pýðingu ólíkrar menningar á heimili og í skóla er einn lykilpátta pess að börnum af erlendum uppruna farnist vel.

Dæmi um hunsun, höfnun og skort á virðingu fyrir sjónarmiðum barnanna fjögurra gæu bent til að börnum af erlendum uppruna sé hættara við útilokun, höfnun og jafnvel einelti. Á grundvelli gagna er bó erfitt að segja til með vissu hvort petta hafi verið raunin. Merki sáust um valda- og virðingarröð sem birtist í pví að pað fengu ekki allar hugmyndir framgang í leik. Par gat skipt máli hver kom með hugmynd og í peim tilfellum hallaði alltaf á börnin sem voru af erlendum uppruna. Ef ekki er unnið með slíka goggunarröð sem hefur náð fótfestu má gera ráð fyrir að hún fylgi börnunum yfir í grunnskóla og að afleiðingar verði líklega alvarlegri par. Dví skiptir pað miklu máli að strax sé unnið að forvörnum gegn einelti og að börnin fái skýr skilaboð um hvaða hegðun er sampykkt og hvaða hegðun ekki. Atriði líkt og ráðgjöf móður um samskiptahegðun sem ekki var viðurkennd í leikskólanum og kom Daniel í erfiða stöðu gagnvart öðrum börnum er svo mögulega aðeins eitt dæmi af fleirum par sem foreldrar pekkja ekki reglur leikskólans. Mikilvægt er að bregðast við slíkum aðstæðum.

Áberandi var á vettvangi að börnin fengu ekki nægilegan stuðning í leikskólastarfinu, sérstaklega ekki í frjálsa leiknum. Рað viðhorf að leikskólakennarinn megi ekki hafa of mikið inngrip í frjálsa leikinn virðist vera nokkuð útbreitt (sjá t.d. Hrönn Pálmadóttur, 2004) en líklegt er að pað valdi pví að pau börn sem purfa stuðning í leiknum fái hann oft á tíðum ekki. Inngrip kennarans beindist að pví að leysa deilur sem komu upp í stað pess að leiðbeina og styðja við leikinn. Mikilvægt er að virða aðferðir barna af erlendum uppruna og sýna peim skilning. Ekki er ólíklegt að leikir peirra byggi á meiri líkamstjáningu og hljóðum en leikir íslenskra barna sem hafa aldurssamsvarandi málbroska. Eins teljum við mikilvægt að börnum af erlendum uppruna sé veittur stuðningur við að komast inn í leikinn með jafnöldrum en með pví hjálpum við peim að mynda félagsleg tengsl innan leikskólasamfélagsins. Bent hefur verið á að tengsl á milli tungumáls, félagsproska og vitsmunaproska séu margpætt og pví nauðsynlegt að líta á pessa pætti sem eina heild (Hrönn Pálmadóttir, 2004; Hrönn Pálmadóttir og Pórdís Dórðardóttir, 2007).

\section{Lokaord}

Í ljósi niðurstaðna er full ástæða til að fylgjast vel með félagslegum tengslum barna af erlendum uppruna á leikskólastiginu. Grunnur að félagslegum samskiptum barna er lagður í leikskóla og félagsleg færni skiptir máli fyrir velferð peirra síðar í lífinu. Dað skiptir pví verulegu máli að öll börn eigi hlutdeild í leik og starfi og að öll börn fái sömu tækifæri til að mynda félagsleg tengsl. Fylgja parf börnum af erlendum uppruna vel eftir í leikskólanum, vera til staðar og styðja pau, ekki síður í frjálsum leik en í skipulögðu starfi. Miklu skiptir að starfsfólk leikskólans sé styðjandi og leiðbeinandi í pví að hjálpa pessum börnum að komast inn í hópinn og eignast vini.

Áhersla hefur oft verið á íslenskukunnáttu barna af erlendum uppruna og vissulega er pað ein af forsendum pess að geta tjáð sig við félaga sína. Í rannsókninni kom glöggt fram að slök íslenskukunnátta var hamlandi páttur í lífi barnanna. Hins vegar má ekki einblína aðeins á íslenskukennslu, félagsleg færni barna skiptir miklu máli og ekki má gleyma pví að tungumálafærni 
byggist fyrst og fremst á samskiptum við aðra. Við purfum að horfa á styrkleika hvers barns og vinna með pá en einblína ekki á pað sem barnið á erfiðara með.

Leiðarljós skóla án aðgreiningar um að öll börn eigi hlutdeild í skólastarfinu og að réttur allra barna sé virtur er lykilatriði í pessu samhengi. Аð barnið njóti virðingar og skoðanir pess og lífsgildi séu metin innan skólasamfélagsins getur haft bein áhrif á félagsleg tengsl pess og möguleika til að mynda vinatengsl við önnur börn. Leikskólinn parf að aðlaga sig að peim barnahópi sem er í skólanum hverju sinni og skapa pannig umhverfi að öll börn fái hlutdeild í skólastarfinu. Skóli án aðgreiningar er pví lykilorðið í fjölmenningarlegu skólastarfi.

\section{„They play together and are happy, it is just so nice“: Social relationships and the reality of foreign-origin pre-school children}

Icelandic studies focusing on foreign-origin compulsory school children and adolescents have shown that they face challenging peer relations. They perceive their classmates as less supportive than Icelandic adolescents do (Eyrún María Rúnarsdóttir \& Rúnar Vilhjálmsson, 2015), they have fewer friends, are teased, feel excluded (Hrefna Guðmundsdóttir \& Hanna Ragnarsdóttir, 2013), and are more exposed to bullying (Dóroddur Bjarnason, 2006). According to Statistics Iceland 12\% of preschool children are currently of foreign-origin (Hagstofa Íslands, 2018), but comparable studies investigating their social relations in the pre-school are not available. Available studies, however, suggest that lack of Icelandic language skills and conflicts between home-culture and school-culture limit the participation of foreign-origin pre-school children in the education practices taking place through free play, social interactions, and friendship relations (Brooker, 2002; Hanna Ragnarsdóttir, 2002).

Respecting and meeting the needs of all children irrespective of their origin is emphasized at all school levels in line with the inclusive education policy of the Icelandic school system. Furthermore, in the National Curriculum Guide for Preschools (Mennta- og menningarmálaráðuneytið, 2011) social interactions and free play are presented as vital parts of pre-school children's education. Also, to promote social skills and competences, developing understanding, respect and consideration for others.

In this paper, a study conducted in pre-school with 5-6-year-old children of foreignorigin is presented. Providing insight into how foreign-origin children establish and navigate friendships, peer relations, and social interactions is a valuable tool in developing multicultural teaching and proper support.

The aim of this qualitative research is to explore the social relations, play, and friendships of pre-school children of foreign-origin. The research questions are: How do children of foreign-origin experience social relations and friendships with their peers? How are these relationships demonstrated in everyday circumstances in the school? What encourages positive relations and social interactions of foreign-origin children with peers and what may deter such relations? The research took place in one department of a pre-school in a small town in the countryside. In total, 21 children participated in the study, the key participants being four 5-6-year-old foreign-origin children, two girls and two boys. Two had parents born in Thailand and two had parents born in Poland. Varied and child-friendly methods were used to collect data: group interviews, paired interviews, individual interviews, videos and field observations. The children took photographs in the pre-school and drew pictures of their friends. A sociogram was created according to friend nominations and the key participants created their friend web. Thematic data analysis revealed three main themes: friendship and social relations, interests, play and social interaction, and finally, language, home culture and school culture. 
Results indicate that while the key participant children enjoyed reciprocal friendships or displayed interest in having many friends, their social relations with peers and friends were delicate. Social interactions with friends and peers were important to them but they had different levels of skills establishing relations and entering their peers' free play. In the group of four we found a likeable, friendly and sociable child, a withdrawn child that seemed to enjoy having just one good friend, a child that did not always read the situation and got into conflicts with other children and a child that preferred playing with other children, but they did not always welcome her. All four children preferred play that did not require much verbal communication and their lack of Icelandic language skills restricted them, for example when needing to make a point and stand their ground in conflicts with peers. Furthermore, there were signs of rejection towards these children. Hierarchy structures and pecking order in social interactions among the children did not favor the foreign-origin children. Some of the children did not have the opportunity to meet friends from school after school hours. It is our conclusion that the four children would have benefitted from better support from their pre-school teachers to ensure their active participation in school activities requiring social interactions. In this regard, it is important to understand which methods foreign-origin children deploy to access play and establish relations. Furthermore, we argue that the pre-school should provide support and guidance to parents to encourage relationship building. Implementing the principles of inclusive education requires special effort to ensure equal access of all children to the learning processes.

Key words: Foreign-origin children, inclusive education, friendship, pre-school, social relationships, multicultural teaching.

\section{Um höfundana}

Eyrún María Rúnarsdóttir (emr@hi.is) starfar sem aðjunkt við Menntavísindasvið Háskóla Íslands og og varði doktorsverkefni sitt frá sama sviði árið 2019. Rannsóknir hennar fjalla um unglinga af erlendum uppruna, líðan peirra, vinatengsl og félagslegan stuðning frá vinum og foreldrum. Eyrún lauk BA-gráđu í uppeldis- og menntunarfræði árið 1996 og meistaragráðu í sömu grein árið 2002 frá Háskóla Íslands.

Svava Rán Valgeirsdóttir (svavava@simnet.is) er leikskólakennari og útskrifaðist úr Fósturskóla Íslands 1992. Hún lauk diplómu í uppeldis- og menntunarfræðum með áherslu á sérkennslufræði árið 2002 og M.Ed-gráđu í sömu grein árið 2016 frá Háskóla Íslands. Svava Rán hefur starfað sem leikskólastjóri og leikskólakennari frá pví hún útskrifaðist 1992. Greinin byggist á lokaverkefni Svövu Ránar í meistaranáminu og var Eyrún María Rúnarsdóttir leiðbeinandi hennar.

\section{About the authors}

Eyrún María Rúnarsdóttir (emr@hi.is) is an adjunct at the School of Education, University of Iceland and defended her doctoral dissertation from the same institution in 2019. Her PhD research is about foreign-origin adolescents' well-being in relation to their sociodemographic background and social support from friends and family. Eyrún completed a bachelor's degree in education studies in 1996 and a master's degree in the same subject in 2002 from the University of Iceland.

Svava Rán Valgeirsdóttir (svavava@simnet.is) is a pre-school teacher and graduated from the Iceland College of Preschool Teachers in 1992. She completed a diploma in 
education studies specializing in inclusive special education in 2002 and an M.Eddegree in the same subject in 2016 from the University of Iceland. Svava Rán has worked as a pre-school teacher and pre-school manager since graduation in 1992. The paper is based on her final thesis in the master's programme in which Eyrún was a supervisor.

\section{Heimildir}

Bagwell, C. L. og Schmidt, M. E. (2011). Friendships in childhood and adolescence. New York: Guilford Press.

Banks, J.A. (2010). Multicultural education: Characteristics and goals. Í J.A. Banks og C.A. Banks (ritstjórar), Multicultural education: Issues and perspectives (7. útgáfa, bls. 3-30). New York: Wiley.

Berglind Rós Magnúsdóttir. (2016). Skóli án aðgreiningar: Átakapólar, ráðandi straumar og stefnur innan rannsóknarsviðsins. Í Dóra S. Bjarnason, Ólafur Páll Jónsson og Hermína Gunnpórsdóttir (ritstjórar), Skóli margbreytileikans i kjölfar Salamanca (bls. 67-94). Reykjavík: Háskólaútgáfan.

Bogdan, R. C. og Biklen, S. K. (2007). Qualitative research for education: An introduction to theories and methods (5. útgáfa) Boston: Pearson.

Boivin, M. (2005). The origin of peer relationship difficulties in early childhood and their impact on children's psychosocial adjustment and development. Í R. E. Tremblay, R. G. Barr og R. D. Peters (ritstjórar), Encyclopedia on early childhood development. Sótt af http://citeseerx.ist.psu.edu/viewdoc/download?doi $=10.1 \cdot 1 \cdot 565.5753 \& \mathrm{rep}=$ rep $1 \&$ type $=$ pdf

Brooker, L. (2002). Starting school:Young children learning cultures. Buckingham: Open University Press.

Corsaro, W. A. (2003). We're friends, right? Inside kids' culture. Washington: Joseph Henry Press.

Corsaro, W. A. (2011). The sociology of childhood (3. útgáfa). Los Angeles: Sage/Pine Forge press.

Dunn, J. (2004). Children's friendships: The beginnings of intimacy. Malden: Blackwell Publishing.

Eyrún María Rúnarsdóttir og RúnarVilhjálmsson. (2015). Ethnic differences in youth well-being:The role of sociodemographic background and social support. Scandinavian Journal of Public Health, 43(6), 580-587. doi:10.1177/1403494815588644

Fanny Jónsdóttir. (2007). Barns kamratrelationer i förskolan: Samhörighet tillhörighet vänskap utanförskap. Sótt af http://dspace.mah.se/bitstream/handle/2043/4984/Fanny MUEP 10 maj.pdf?sequnce=1

Ferguson, D. L., Ralph, G., Meyer, G., Lester, J., Droege, C., Hafdís Guðjónsdóttir, ...Williams, J. (2012). Nám fyrir alla. Undirbúningur, kennsla og mat i skóla margbreytileikans (Ásta Björk Björnsdóttir pýddi). Reykjavík: Háskólaútgáfan.

Flick, U. (2006). An introduction to qualitative research (3. útgáfa). London: Sage.

Graham, S., Munniksma, A. og Juvonen, J. (2014). Psychosocial benefits of cross-ethnic friendships in urban middle schools. Child Development, 85(2), 469-483. doi:10.1111/cdev.12159

Graham, S., Taylor, A. Z. og Ho, A.Y. (2009). Race and ethnicity in peer relations research. Í K. H. Rubin,W. M. Bukowski og B. Laursen (ritstjórar), Handbook of peer interactions, relationships, and groups (bls. 394-413). New York: Guilford Press.

Hagstofa Íslands. (2018). Börn í leikskólum með erlent móđurmál 1998-2017. Sótt af http://px.hagstofa.is/ pxis/pxweb/is/Samfelag/Samfelag skolamal 1 leikskolastig 0 lsNemendur/SKO01103.px/table/ tableViewLayout 1/?rxid=45571131-971e-4c19-b3d7-21967f9aa7e2

Hanna Halldóra Leifsdóttir. (2014). „,Detta er bara partur af menningunni hér og maður verður bara að synda með“: Upplifun erlendra foreldra af pví að byrja með barn í íslenskum leikskóla (óútgefin meistararitgerð). Háskóli Íslands, Reykjavík.

Hanna Ragnarsdóttir. (2002). Markvisst leikskólastarf í fjölmenningarlegu samfélagi. Uppeldi og menntun, 11(1), 51-80.

Hanna Ragnarsdóttir. (2004).Vilji og væntingar: Rannsókn á áhrifapáttum í skólagöngu erlendra barna á Íslandi. Uppeldi og menntun, 13(1), 91-110. 
Hanna Ragnarsdóttir. (2010). Fjölbreyttir kennarahópar og fjölbreyttir nemendahópar. Ráđstefnurit Netlu Menntakvika 2010. Sótt af http://netla.hi.is/menntakvika2010/012.pdf

Hrefna Guðmundsdóttir og Hanna Ragnarsdóttir. (2013). Líðan, félagsleg tengsl og pátttaka nemenda í 5.-7. bekk grunnskóla í frístundastarfi: Samanburður á svörum barna eftir móðurmáli töluðu heima. Tímarit um menntarannsóknir, 10, 123-140.

Hrönn Pálmadóttir. (2004). Boðskipti í leikskóla: Athugun á boðskiptum barna með samskiptaerfiðleika og íhlutun starfsmanna. Uppeldi og menntun, 13(2), 97-122.

Hrönn Pálmadóttir og Jóhanna Einarsdóttir. (2012).Yngstu leikskólabörnin: Samfélag í leik. Uppeldi og menntun, 21(2), 43-69.

Hrönn Pálmadóttir og Dórdís Dórðardóttir. (2007). „Баð sem áđur var bannað er nú leikur“. Breytingar á uppeldissýn í leikskóla. Tímarit um menntarannsóknir, 4, 119-135.

Jóhanna Einarsdóttir. (2007). Research with children: Methodological and ethical challenges. European Early Childhood Education Research, 15(2), 197-211.

Ladd, G. E., Birch, S. H. og Buhs, E. S. (1999). Children's social and scholastic lives in kindergarten: Related spheres of influence? Child Development, 70(6), 1373-1400.

Lára Jóna Dorsteinsdóttir. (2008). Mig langar a lara: Nám og líðan unglingsstúlkna af erlendum uppruna i íslenskum grunnskóla (óutgefin meistararitgerð). Sótt af http://hdl.handle.net/1946/1893

Manning-Morten, J. og Thorp, M. (2003). Key times for play: The early years. Philadelphia: Open University Press.

McGill, R. K., Way, N. og Hughes, D. (2012). Intra- and interracial best friendships during middle school: Links to social and emotional well-being. Journal of Research on Adolescence, 22(4), 722-738. doi:10.1111/j.15327795.2012.00826.x

Mennta- og menningarmálaráđuneytið. (2011). Aðalnámskrá leikskóla. Reykjavík: Höfundur.

Nína V. Magnúsdóttir. (2010). „Allir vilja eignast íslenskar vinir“. Hverjar eru helstu hindranir á vegi erlendra grunn- og framhaldsskólanemenda i íslensku skólakerfi? (óútgefin meistararitgerð). Sótt af http://hdl.handle.net/1946/4576

Pettigrew, T. F. og Tropp, L. R. (2008). How does intergroup contact reduce prejudice? Meta-analytic tests of three mediators. European Journal of Social Psychology, 38(6), 922-934.

Sebanc, A. M. (2003). The friendship features of preschool children: Links with prosocial behavior and aggression. Social Development, 12(2), 249-269. doi:10.1111/1467-9507.00232

Suárez-Orozco, C., Suárez-Orozco, M. M. og Todorova, I. (2009). Learning a new land: Immigrant students in American society. Cambridge: Harvard University Press.

Póra Björk Ágústsdóttir. (2008). Félagslegar aðstæður innflytjenda á Akureyri (óútgefin BA-ritgerð). Sótt af http://hdl.handle.net/1946/1604

Dóroddur Bjarnason. (2006). Aðstæður íslenskra skólanema af erlendum uppruna. Í Úlfar Hauksson (ritstjóri), Rannsóknir í félagsvísindum VII: Félagsvísindadeild (bls. 391-400). Reykjavík: Félagsvísindastofnun Háskóla Íslands.

Eyrún María Rúnarsdóttir og Svava Rán Valgeirsdóttir (2019)

„Deir leika saman og eru glaðir, pað er bara svo gott“: Félagsleg tengsl og vinátta leikskólabarna af erlendum uppruna

Netla - Veftímarit um uppeldi og menntun. Menntavísindasvið Háskóla Íslands.

Sótt af http://netla.hi.is/serrit/2019/menntun_barna_leik_grunn/03.pdf

DOI: https://doi.org/10.24270/serritnetla.2019.35 